\title{
Curie point depth and heat flow deduced from spectral analysis of magnetic data over Adamawa volcanic region (Northern Cameroon): geothermal implications
}

\author{
Kasi Njeudjang ${ }^{1,2} \cdot$ Janvier Domra Kana ${ }^{1,3} \cdot$ Ahmat Tom $^{4} \cdot$ Jean Marcel Abate Essi ${ }^{5} \cdot$ Noël Djongyang $^{1} \cdot$ René Tchinda $^{6}$
}

Received: 28 January 2020 / Accepted: 16 June 2020 / Published online: 4 July 2020

(c) Springer Nature Switzerland AG 2020

\begin{abstract}
This study presents an estimation of Curie point depth (CPD), heat flow and geothermal gradient from spectral analysis over the Adamawa volcanic region (northern Cameroon). The spectral analysis method is applied to the reduced-toequator (RTE) magnetic anomaly data of the region. Grid Earth Magnetic Anomaly (EMAG2) data were divided into 17 zones. RTE magnetic anomaly data were low-pass filtered to remove the effects of topography. Then, the data were transformed into the Fourier domain in order to determine the spectrum of the magnetic anomaly data for the study region. Then, the depth values are used to estimate the CPD, the geothermal gradient (GG) and the heat flow in the Adamawa region of Cameroon (Central Africa). The acquired results indicate that the CPD varies between 15.97 and $41.16 \mathrm{~km}$ with an average of $27.52 \mathrm{~km}$. GG varies between 14.09 and $36.31^{\circ} \mathrm{C} \mathrm{km}^{-1}$ with an average of $22.27^{\circ} \mathrm{C} \mathrm{km}^{-1}$ and the resulting heat flow varies between 35.23 and $90.78 \mathrm{~mW} \mathrm{~m}^{-2}$ with an average of $55.68 \mathrm{~mW} \mathrm{~m}^{-2}$. The variation in heat flow and GG shows an abnormal geothermal condition of the area. It is found that there is a geothermal potential precisely at Woulndé in the Adamawa region. The obtained results can serve as a guide for government and private partners to explore this energy source.
\end{abstract}

Keywords Curie point depth · Heat flow · Spectral analysis · Geothermal gradient · Energy

\section{Introduction}

Energy is one of the key development factors (economic, social) in Cameroon (Central Africa). The country is bursting with renewable energy resources such as biomass, wind power, solar energy, and geothermal energy, which remain largely unexploited. The particularity of the Adamawa region (northern Cameroon) seems to be favorable to the study of geothermal resources in sub-Saharan Africa according to its geological context [1]. Most phenomena such as volcanism, earthquakes, mountain formation associated with tectonic plates are controlled by heat transfers in the Earth.

Several authors have been studied the geological context of the Adamawa region of Cameroon [2-10, 26, 28-30]. Geophysical studies (gravimetric, seismic, magnetic and magnetotelluric) have been carried out by authors of Ref [2]. in a regional context. Noutchogwe

Kasi Njeudjang, kasinj2006@yahoo.fr |'Department of Renewable Energy, National Advanced School of Engineering of Maroua, University of Maroua, PO. Box: 46, Maroua, Cameroon. ${ }^{2}$ Department of Quality Industrial Safety and Environment, Faculty of Mines and Petroleum Industries, University of Maroua, PO. Box: 46, Maroua, Cameroon. ${ }^{3}$ Department of Mines, Petroleum and Water Resource Exploration, Faculty of Mines and Petroleum Industries, University of Maroua, PO. Box: 46, Maroua, Cameroon. ${ }^{4}$ Department of Energy Engineering, University Institute of Technology, University of Ngaoundere, PO. Box: 455, Ngaoundere, Cameroon. ${ }^{5}$ Ore Processing Laboratory, Institute for Geological and Mining Research, PO. Box: 4110, Nlongkak Yaoundé, Cameroon. '́laboratoire D'Ingénierie Des Systèmes Industriels Et de L'Environnement(LISIE), Fotso Victor University Institute of Technology University of Dschang, PO. Box: 134, Bandjoun, Cameroon. 
[3] revealed the existence of a deep structural contrasts located beyond the crust. Geodynamic and tectonic models showed deep and superficial structures. The aeromagnetic data analysis over Foumban fault in western Cameroon illustrated that they are tectonically related to the Adamawa region. This suggests that it is characterized by rocks with different magnetic susceptibilities [4]. It highlights the $\mathrm{N} 30^{\circ} \mathrm{E}$ tectonic direction identical to that described by the interpretation of satellite images [5]. There are also seismological studies $[6,7]$, which made it possible to prove the existence of a thin crust of about $23 \mathrm{~km}$, under the Adamawa. The authors of Ref [8]. estimated that the average crustal thickness is about $36 \mathrm{~km}$ in the Adamawa. However, the Kumba Graben and the Mamfe Basin in southern Cameroon varies between 28 and $31 \mathrm{~km}$. Kande [9] carried out a study around the Mbere tectonic graben proving that the granito-gneissic bedrock has a resistivity of more than $10,000 \mathrm{~m}$. The geological faults, as well as fissures of the ground, folds, and dykes make it possible to explore the geothermal structure of the Cameroon Volcanic line (CVL) [10].

Several researchers used magnetic data to evaluate spectral CPD in different parts of the world in order to explore gas, oil and others resources [11-25]. In this paper, we estimate CPD, geothermal gradient, and heat flow values using spectrum analysis of the Grid Earth Magnetic Anomaly (EMAG2) for geothermal investigation in the Adamawa volcanic area. This paper is organized as follows. In addition to Sect. 1 (Introduction), Sect. 2 is devoted to the geology in the Adamawa region. Section 3, data and method used to achieve the aims of this paper are presented. Sections 4 and 5 focus on the result and discussion respectively. The conclusion is given in Sect. 6 .

\section{Geology}

Adamawa region of Cameroon covers an area of 63,701 $\mathrm{km}^{2}$. It is located between the latitudes $6^{\circ} 00^{\prime}$ and $8^{\circ} 00^{\prime} \mathrm{N}$ and of the longitudes $11^{\circ} 00^{\prime}$ and $15^{\circ} 00^{\prime} \mathrm{E}$ as shown in Fig. 1.

Adamawa volcanic region presents physical characters comprising mountainous massifs, having trays and basins. Geological diversity belongs to several sets. The basement, metamorphosed sedimentary series, sedimentary and volcanic series constitute the major geological elements in the region. Several tectonic structures such as the Foumban Shear Zone (FSZ), the CVL and the southern basin of Adamawa are available in the study region [26]. The FSZ is part of the Central African Shear Zone (CASZ), which is a succession of Pan-African major ENE-WSW faults zones stretching about $2000 \mathrm{~km}$ from Cameroon to Sudan $[27,28]$. The Central Shear Zone of Cameroon (CCSZ) is located on the Adamawa volcano region whose orientation is $\mathrm{N} 30^{\circ} \mathrm{E}$. Various plutonic rocks (granites, diorites, syenites, gabbros) of mantle origin and hyper alkaline affinity, associated with volcanic rocks, are androgenic complexes along the CVL.

The authors of Ref [29]. proposed a tectonic evolution of the region whose main sequences would be the following:

- In Precambrian: The establishment of large fracture zones, resulting from a very important compressive tectonics that corresponds to the Pan-African orogenic cycle. This fracturing phase prepares zones of weakness with the dislocation of the Gondwana from the beginning of the Cretaceous.

- In Upper Cretaceous: Dislocation of Gondwana corresponds to the formation of intracontinental basins (Benue and Djerem in Cameroon, Doba, Baké-Birao and Bousso in Southern Chad and Northern Central African Republic and the opening of the Atlantic Ocean), subsequent reactivation of the CCSZ and associated fracture zones. During this tectonic process, the lithosphere is subjected to extensive lateral stresses that cause its thickness thinning, the upper mantle to decompress, partially melt and the magmatic fluid generated to rise through lithospheric fractures. The origin of the crustal thinning is related to the rise of the asthenosphere, which causes a lithospheric bulge and subsequent stretching of the Earth's crust. The topographic expression of this isostatic process is the formation of a plateau accompanied by brittle tectonics characterized by cracks and fractures in the crust, sometimes interspersed with pre-existing Pan-African faults. These fractures will be the main access road for the placement of lava in the Adamawa Cenozoic.

- In Cenozoic: The shocks of the CCSZ will either encourage the magma to rise to the surface through the fracture zones of the substrate, giving rise to fissural volcanism, or allow the collection and blocking of the magmatic fluid, in "intracrustal pockets" "preferably located in line with large fractures.

\section{Data and method}

\subsection{Data}

Magnetic data used in this study are derived from a compilation of satellite, marine and airborne measurements. All the data were used for the development of the EMAG2 [31]. The magnetic anomaly grid was acquired at an altitude of $4 \mathrm{~km}$ above mean sea level with a resolution of 2 arc minutes to $2 \mathrm{~min}$. The resolution was from 2 arc 


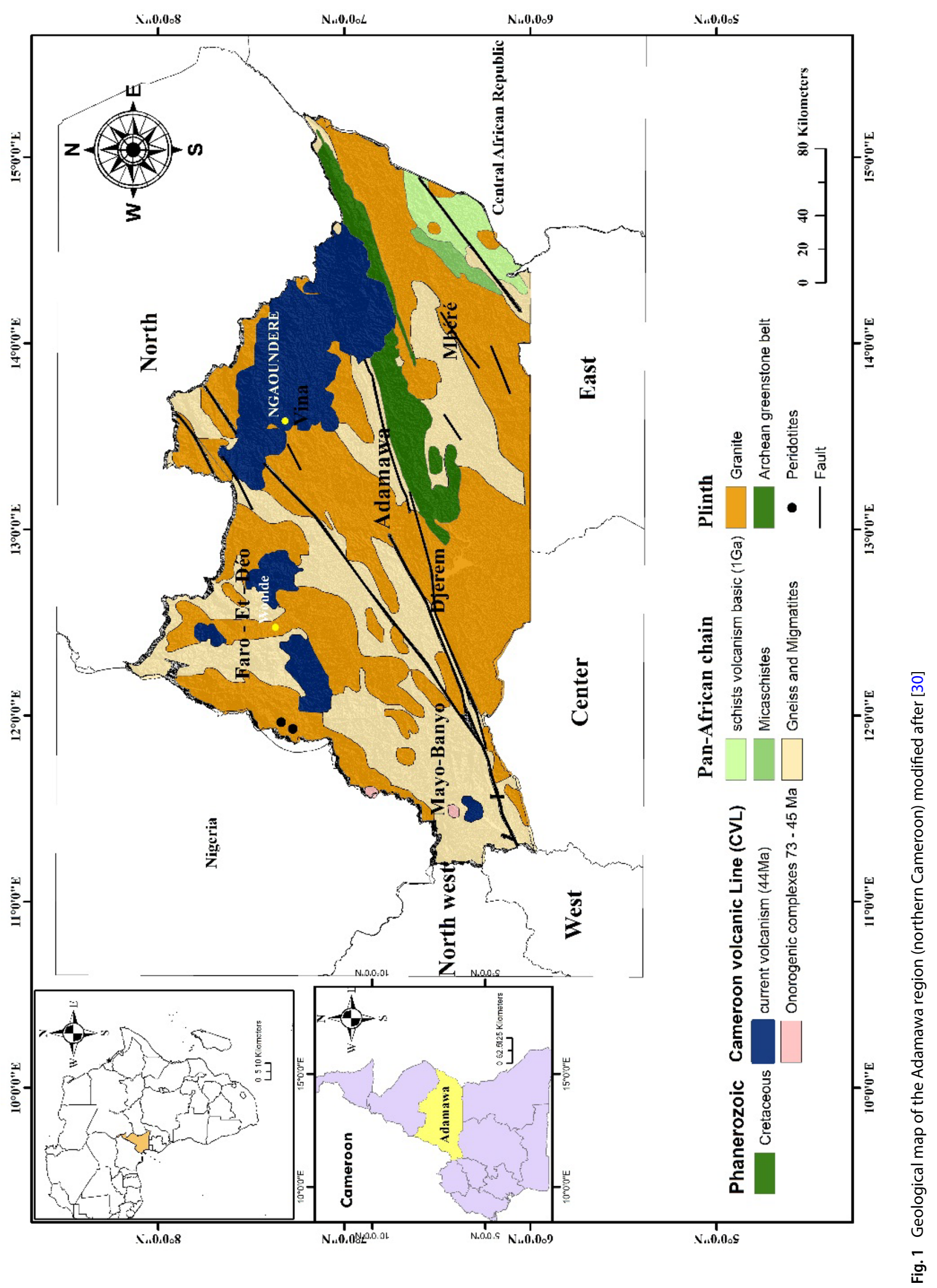


minutes to 3 arc minutes. The altitude was also reduced from 4 to $5 \mathrm{~km}$ above the geoid [31].The Total Magnetic Intensity Anomaly (TMI) was derived by subtracting the International Geomagnetic Reference Field (IRGF) of each station. The TMI was reduced at the equator (RTE) to correct the asymmetries in the observed anomalies related to the magnetization direction. The RTE correction applied allows a tilt of $-10.98^{\circ}$ and a declination of $-0.9^{\circ}$ using the Fast Fourier Transform Filtering (FFTFIL) program [32, 33].

\subsection{Method}

Spectral methods have been generally used to determine isothermal Curie depth $[11,12,14-16]$. These methods helped to better determine the regional CPD by examining the spectral properties of magnetic anomalies over relatively large areas [12,34]. Some researchers have also used CPD values to explore the geothermal structure of the Earth's crust; as an example [35-37]. As a part of this study, the spectral analysis approach is performed to determine the upper limit and the centroid depth of magnetic sources. The spectral analysis method is applied to the reduced-to-equator magnetic anomaly data of region. Reduced-to-equator magnetic data were low-pass filtered to remove the effects of topography. Then, the data were transformed into the Fourier domain in order to determine the spectrum of the magnetic anomaly data from the study region. This method determines the depth to the top $\left(Z_{t}\right)$, center $\left(Z_{\mathrm{o}}\right)$ and bottom $\left(Z_{b}\right)$ of magnetic sources. The deduced results were used to estimate the base of the magnetic sources (CPD) by using the following three steps [11]:

- Phase 1:

Estimation of the depth to the centroid $\left(Z_{\mathrm{o}}\right)$ of the magnetic sources from the slope of the lower frequency component segment of the energy spectrum.

- Phase 2:

Estimation of the depth to the upper limit $\left(Z_{t}\right)$ of the magnetic sources from the slope of the upper-frequency component segment of the energy spectrum.

- Phase 3:

Finally, to calculate the base depth $\left(Z_{b}\right)$ assumed to represent the required CPD in each window, the following simple mathematical relationship was used:

$Z_{\mathrm{b}}=2 Z_{\mathrm{o}}-Z_{\mathrm{t}}$

Geothermal gradient is defined as the rate of increase in temperature relative to the increase in depth within the Earth. The average depth of the gradient is around $25-30{ }^{\circ} \mathrm{C} \mathrm{km}^{-1}$ for regions far from the limits of tectonic plates in the world. This slope decreases as one sinks deeper beneath the surface of the Earth; hence the thermal conductivity of rocks usually increases with depth. In addition, there is no exact information on the thermal conductivity of deep rocks. Geothermal gradient $\left(\frac{\mathrm{d} T}{\mathrm{~d} Z}\right)$ of the earth's surface at CPD $\left(Z_{\mathrm{b}}\right)$ can be estimated as follows $[11,15]$ :

$\operatorname{grad} T=\frac{\mathrm{d} T}{\mathrm{~d} Z}=\frac{\theta_{\mathrm{C}}}{Z_{\mathrm{b}}}=\frac{580^{\circ} \mathrm{C}}{Z_{\mathrm{b}}}$

where $\theta_{c}$ is the Curie temperature having an approximate value of $580^{\circ} \mathrm{C}_{;} Z_{\mathrm{b}}$ is the curie depth. Nevertheless, the geothermal gradient is under the following three assumptions:

i. No existence of heat sources or heat sinks between the surface of the Earth and the CPD,

ii. The surface temperature is $0^{\circ} \mathrm{C}$, and

iii. $\frac{d T}{d Z}$ is the temperature gradient, the heat flux $\left(Q_{Z}\right)$ can also be estimated as [11]:

$$
Q_{Z}=K \frac{\theta_{C}}{Z_{\mathrm{b}}}=K \frac{\mathrm{d} T}{\mathrm{~d} Z}
$$

where $K$ is thermal conductivity. Thermal conductivity of $2.5 \mathrm{Wm}^{-1}{ }^{\circ} \mathrm{C}^{-1}$ is considered average for igneous rocks and the curie temperature of $580^{\circ} \mathrm{C}$. This value is a reasonable value for Curie temperature in the continental crust [38, 39].

\section{Results}

The constructed TMI anomaly map (Fig. 2) reveals a series of positive and negative magnetic anomalies of different sizes, shapes and amplitudes, polarities and extensions. This wide variation reflects different sources, depths and compositions.

The map shows that most of the anomalies are aligned in $\mathrm{E}-\mathrm{W}$ directions with sharp and smooth gradients. These different trends clearly show that the area is affected by different tectonic forces over its geological history. Negative short-wavelength, low-extension anomalies are located in the SW and NE portion of the Study area. These anomalies may be due to shallow magnetic sources [47]. On the other hand, positive long-wavelength, longextension anomalies extend from Ngaoundéré to Kontcha localities and at the SE Meiganga.

The obtained RTE magnetic anomaly map is given in Fig. 3.

Figure 3 presents a series of positive and negative magnetic anomalies with a particularity for their sizes, shapes, amplitudes and polarities. This large variation reflects 
different sources, depths and compositions ranging from $-85.9 \mathrm{nT}$ to $126.9 \mathrm{nT}$. Anomalies have the same direction NW-SE whose contours result in elongated and ovoid lobes with strong gradients. These different trends also show that the region is affected by different tectonic-magmatic forces during the recent volcanic eruption and geological facts. They consist of small, medium and longwavelength anomalies. The short-wavelength anomalies are located in the Southeastern and Southwestern of the axis of uplift, which is attributed to the effect of crustal thinning [2]. They may be due to shallow magnetic sources due to the cretaceous uplift on the Northeastern side of Cameroon [4]. On the other hand, the long-wavelength anomalies extend from the Northwest with an extension to the west located in the African craton. Nevertheless, RTE magnetic data present magnetic sources at different depths. Our results are in correlation with that of which states that a major discontinuity located between 8 and $20 \mathrm{~km}$ [40]. The comparison between the aeromagnetic map of total intensity in Fig. 2 and RTE in Fig. 3 shows a shift toward the north. The shapes and magnitudes of the magnetic anomalies are slightly modified due to the suppression of the tilt effect and the declination of the magnetic field. The RTE map is separated into 17 superimposed square sub-zones with a size of 110 by $110 \mathrm{~km}$ represented by the zone numbers in Fig. 4.
In Fig. 4, the centers of the zones are marked by a black circle. In each zone, the power spectrum was performed using the Oasis Montaj 6.2 software to find out the depth of the magnetic sources at the top $\left(Z_{t}\right)$ and centroid $\left(Z_{o}\right)$. Using Eq. (1),CPD $\left(Z_{b}\right)$ is calculated according to the procedure given above [11].

The geothermal gradient $(\operatorname{grad} T)$ is calculated using Eqs. (2) and (3) in order to estimate the heat flow of the study region. The temperature of the Curie point is assumed to be $580^{\circ} \mathrm{C}$ and the thermal conductivity of $2.5 \mathrm{~W} \mathrm{~m} \mathrm{~m}^{-1} \mathrm{C}^{-1}$ with the average value for the igneous rocks located above the basement. The temperature of the Curie point is between 500 and $600{ }^{\circ} \mathrm{C}$ in the literature $[11,14]$. The authors of Ref [17]. generalized that $580^{\circ} \mathrm{C}$ is a reasonable value for Curie temperature in the continental crust. The results of the estimated depths, geothermal gradient, and heat flow for the 17 sub-zones are shown in Table 1.

Figure 5 presents the power spectrum of the aeromagnetic data of the different zones.

Based on the radially average power spectrum curves plotted above, we observe coherence in the distribution of the three surfaces $\left(Z_{\mathrm{t}}, Z_{\mathrm{o}}\right.$, and $\left.Z_{\mathrm{b}}\right)$. The base depth $Z_{\mathrm{b}}$ shows a certain ondulation at the $Z_{\mathrm{t}}$ and $Z_{\mathrm{o}}$ surfaces. Within the Earth, the CPD is relatively shallow, in the crust or in the most superficial areas of the upper mantle. Table 1 presents the results of the estimated depth ranges for the 17

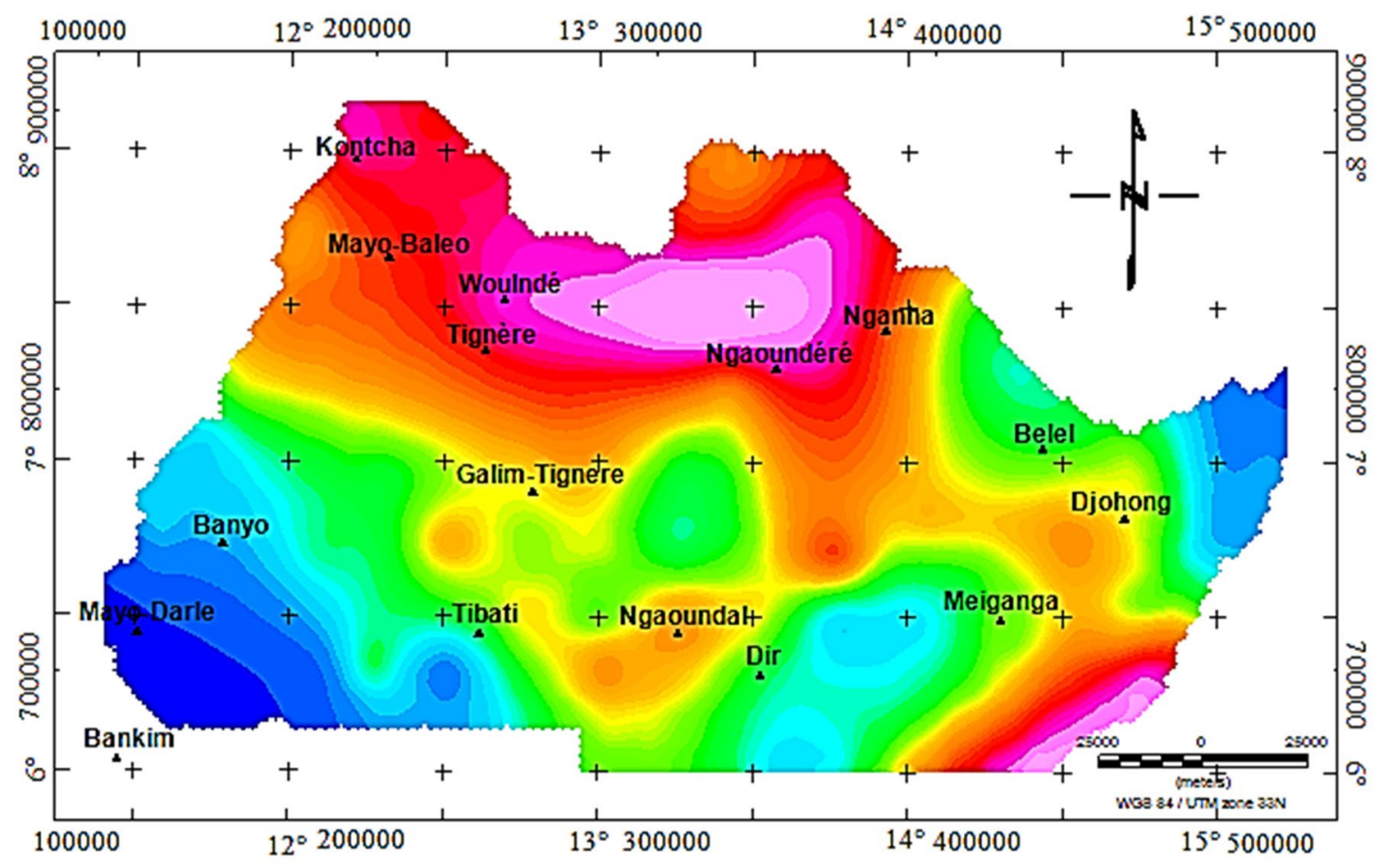

Fig. 2 Total magnetic intensity (TMI) Anomaly map of the Adamawa region. The counter interval is $-121.2 \mathrm{nT}$ to $134 \mathrm{nT}$ 
sub-zones. The graph of the spectral energies used estimates the Curie point. It also indicates the depth at the top of the magnetic source. The result obtained ranges from $10.128 \pm 0.983$ to $22.517 \pm 0.995 \mathrm{~km}$ with an average value of $15.972 \pm 0.973 \mathrm{~km}$. Centroid depth is between $2.694 \pm 0.919$ and $7.8 \pm 0.993 \mathrm{~km}$ with an average value of $4.357 \pm 0.939 \mathrm{~km}$ and the CPD values vary between $15.972 \pm 0.973$ and $41.158 \pm 1.078 \mathrm{~km}$ and an average value of $27.526 \pm 1.020 \mathrm{~km}$. Depth knowledge allows the geothermal gradient and near-surface heat flow calculation in the study region. Figure 6 shows the variation of CPD values in the Ngaoundéré-Mayo Baléo area with the shallower parts (less than $22 \mathrm{~km}$ ) in NNE and SSW; while the maximum value is located in the northern part (Ngaoundéré).

This gives a clue to the expected nature of basement rocks. Table 1 gives geothermal gradient values vary between 14.092 and $36.313^{\circ} \mathrm{C} \mathrm{km}^{-1}$ with an average value of $22.25^{\circ} \mathrm{C} \mathrm{km}^{-1}$. While the parameters of heat flow vary between $35.230 \mathrm{~mW} \mathrm{~m}^{-2}$ and $90.782 \mathrm{~mW} \mathrm{~m}^{-2}$ with an average value of $55.681 \mathrm{~mW} \mathrm{~m}^{-2}$. High temperature gradient encountered in the study area is due to the recent volcanic eruption. Localities of Mayo Baléo, Woulndé and Tignère have heat flows of the order of at least $80 \mathrm{~mW} \mathrm{~m}^{-2}$. These results are of interest for further geothermal exploration according to $[35,41,42]$. These high heat flow values are considered as large-scale mantle upwelling. It is considered to be a strong crustal heat within lithospheric rocks. This leads us to report the presence of granitic rocks with a concentration of radioactive elements. Another geothermal study would be recommended to confirm this abundance as a geothermal resource in the localities of Tignère, Woulndé and Mayo Baléo. Nevertheless, our results present Woulndé as a favorable place for a power plant installation $[43,44]$. In this zone, the temperature of the hot spring is $74^{\circ} \mathrm{C}$. It is the highest temperature of the Cameroon Volcanic Line. Finally, all the criteria examined seem sufficiently concordant to say that the thermal springs of Woulndé constitute a thermal potential for Adamawa. We highlighted the variation of the gradient and the heat flow as a function of the CPD. Figure 7 shows the variation of the geothermal gradient and geothermal heat flow with estimated CPD values, respectively.

The plots of the Geothermal Gradient versus Curie temperature depth and heat flow versus Curie temperature depth values reveals that they are inversely proportional with a relationship of $\mathrm{GG}=580.79 \mathrm{Zb}^{-1}$ and $Q=1452 \mathrm{Zb}^{-1}$, respectively, in the research area. In this figure, the geothermal gradient and heat flow decrease with the increasing Curie depth values. The heat variation is solely due to the influence of the geothermal water gradient of the
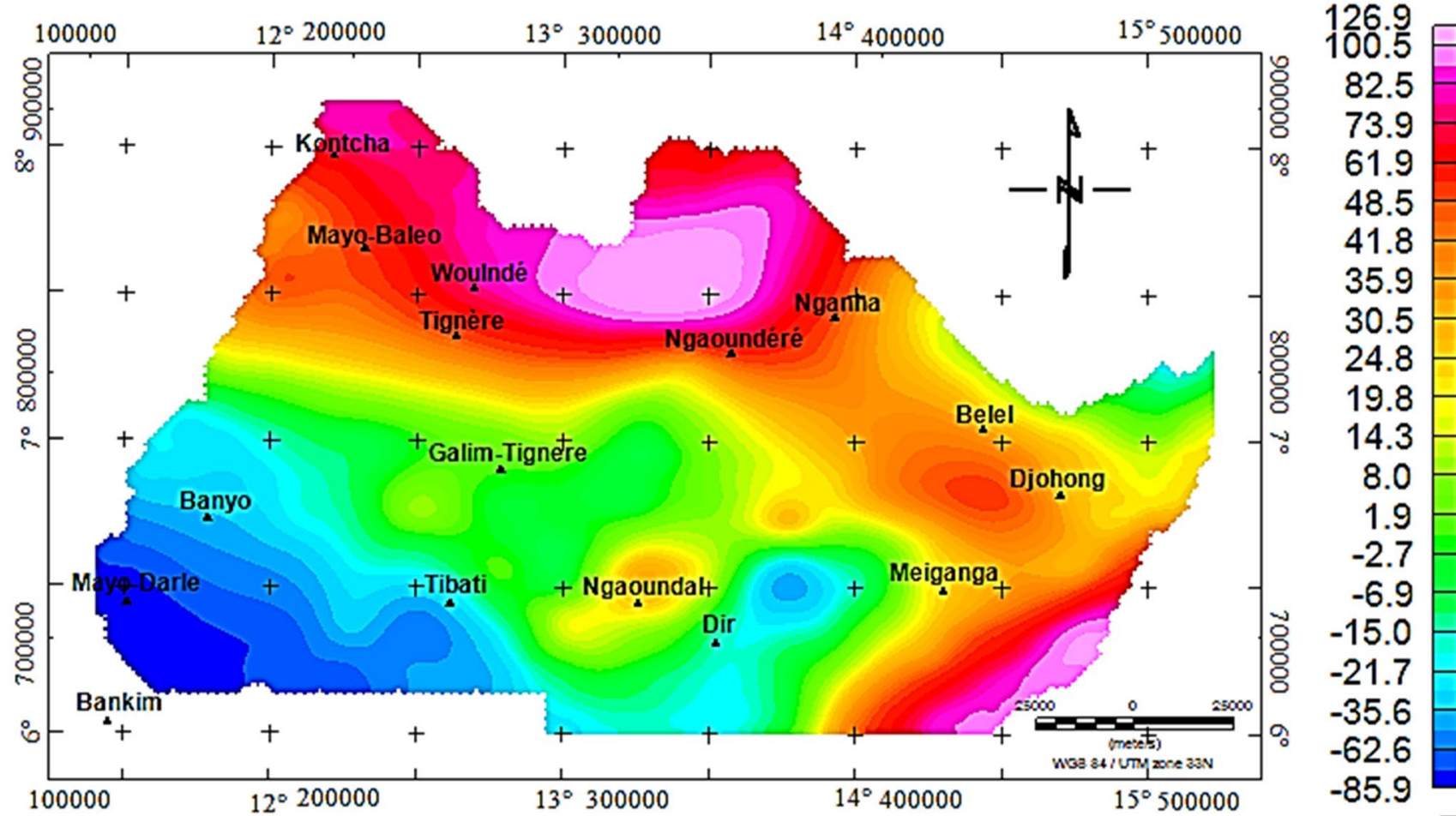

Fig. 3 Reduced-to-equator magnetic intensity map of the Adamawa region. The counter interval is $-85.9 \mathrm{nT}$ to $126.9 \mathrm{nT}$ 


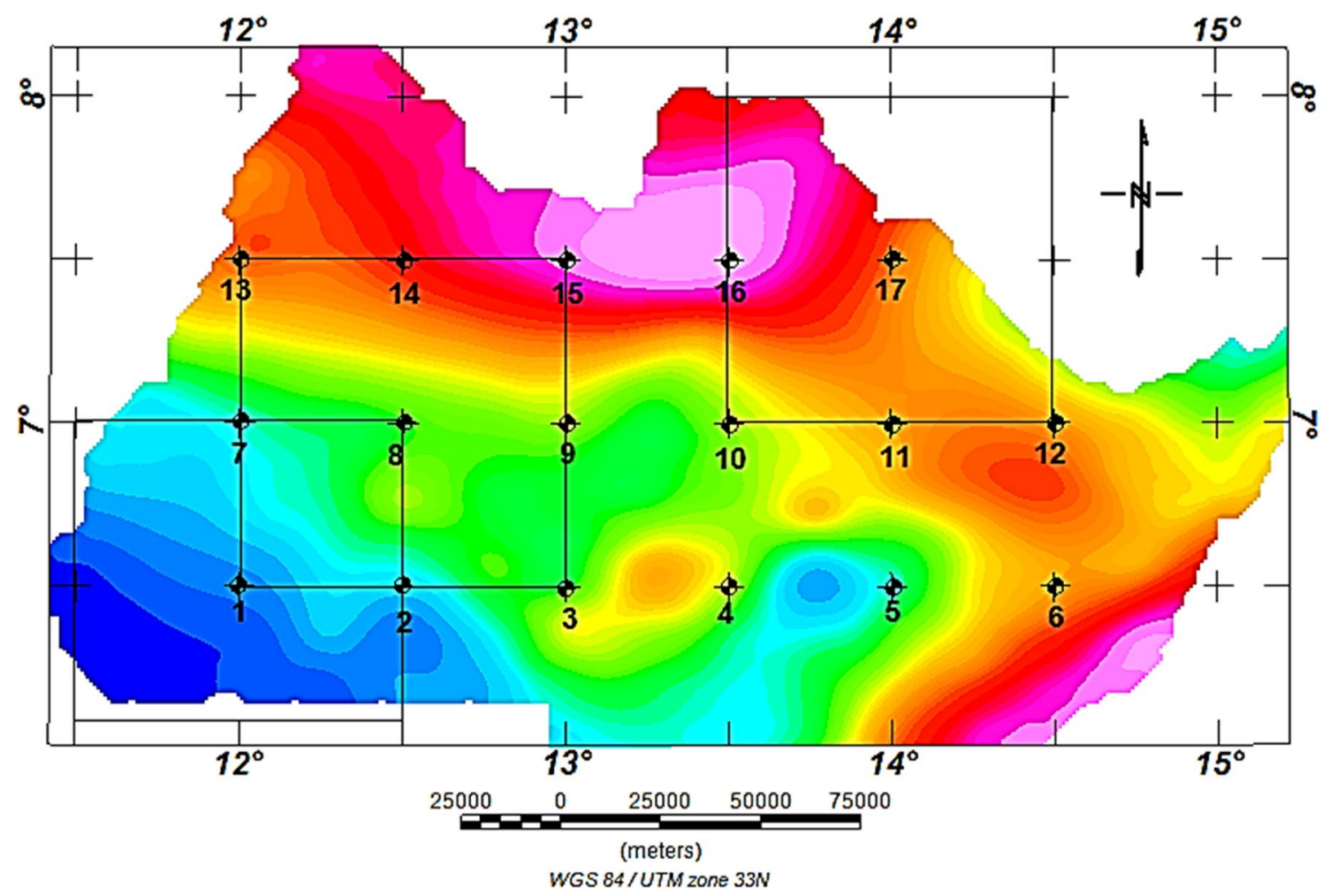

Fig. 4 Map showing the 17 overlapping area used for power spectral analysis. Each $1^{\circ}$ by $1^{\circ}$ blocks is denoted by a number at its center. The counter interval is $-85.9 \mathrm{nT}$ to $126.9 \mathrm{nT}$

hottest spring, this heat flow is apparently due to volcanic phenomena.

\section{Discussion}

The application of spectral analysis method to aeromagnetic data gives acceptable geological results. Geothermal exploration in this region should be the subject of future researches. The aeromagnetic map of total intensity is first reduced to the equator to correct the shape and position of the different bodies. Besides, short-wavelengths anomalies are eliminated to improve long-wavelengths anomalies related to deep sources. Spectral analysis method indicates that the region is underlain by an average CPD of about $27.526 \pm 1.020 \mathrm{~km}$. The results obtained from the
EMAG2 data shows that the amplitude of this great anomaly increases when one goes toward the low altitudes. This presents a so-called Bangui anomaly with a deep and not superficial origin according to Refs. $[45,46]$. It may also be of lithospheric origin [7]. The analysis of the aeromagnetic map according to [47] suggests that the region is characterized by rocks of different magnetic susceptibilities. Also, this study highlights the $\mathrm{N} 30^{\circ} \mathrm{E}$ tectonic direction identical to the one described by the interpretation of satellite images [5]. Figures 8 and 9 show the geothermal gradient and heat flow contour maps, respectively.

Several demonstrations on the surface of the Adamawa attest the presence of hot materials at depth. This is the case of the hydrothermal vents located in the Mayo Baléo,Tignère and Woulndé which release hot fluids. The recent volcanic eruptions near the CVL show sharp and 


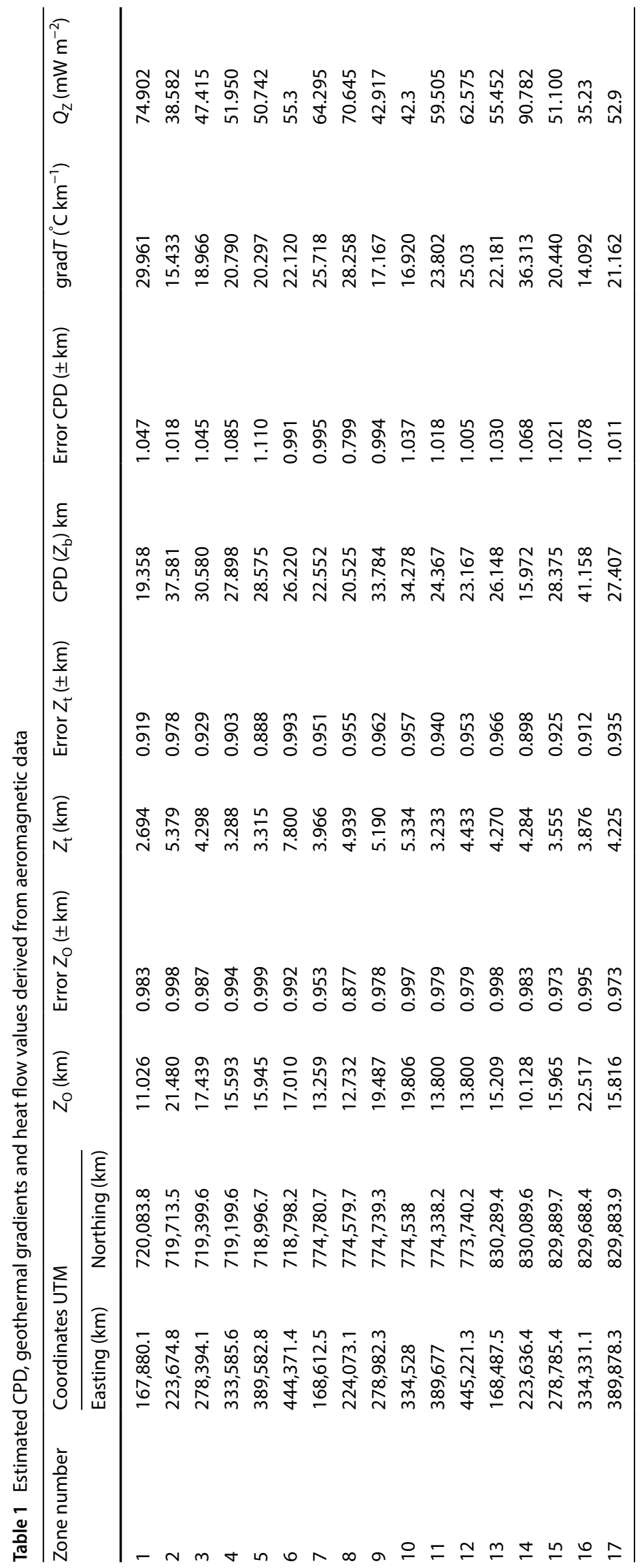


(a)
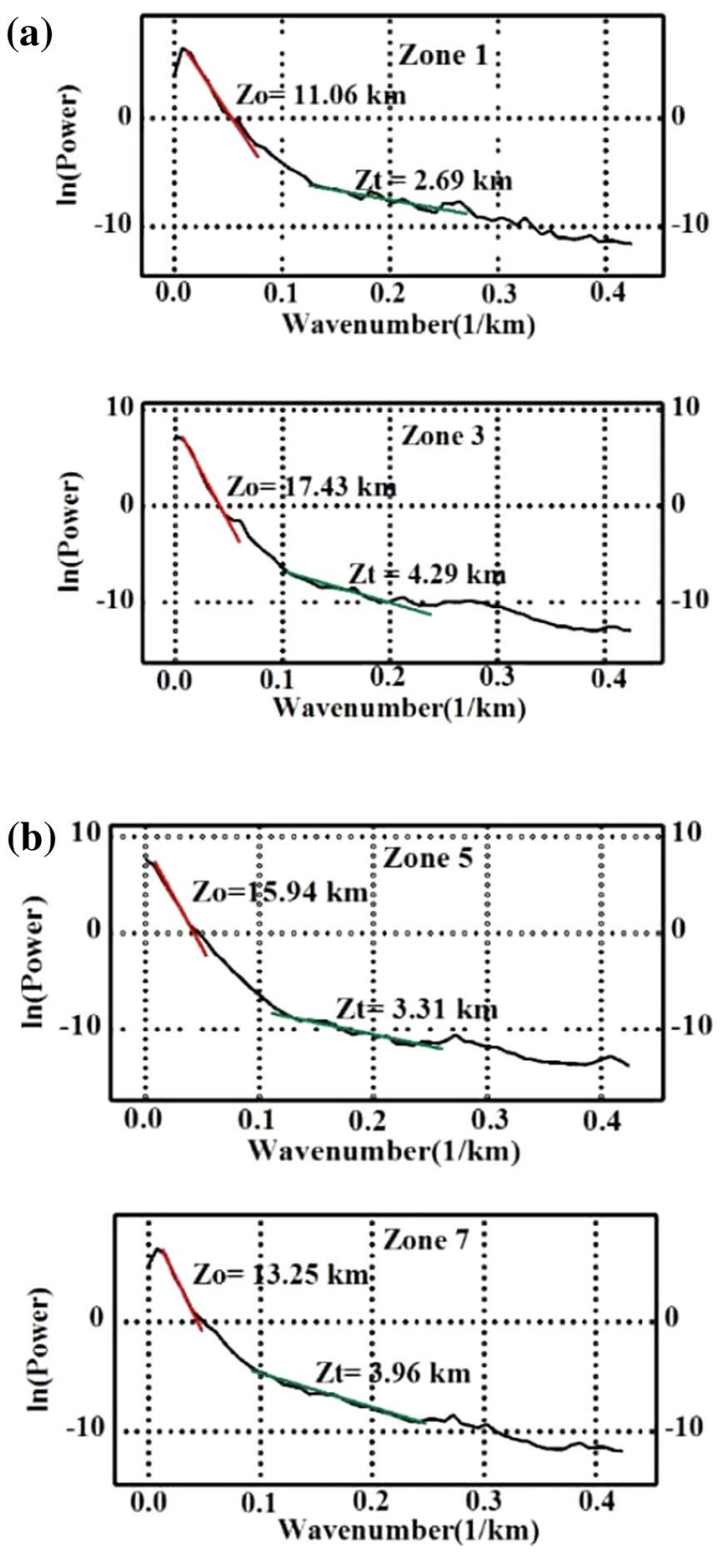

Fig. 5 a Radially average power spectrum used for estimating CPD of 4 zones. b Radially average power spectrum used for estimating CPD of 4 zones. c Radially average power spectrum used for esti-
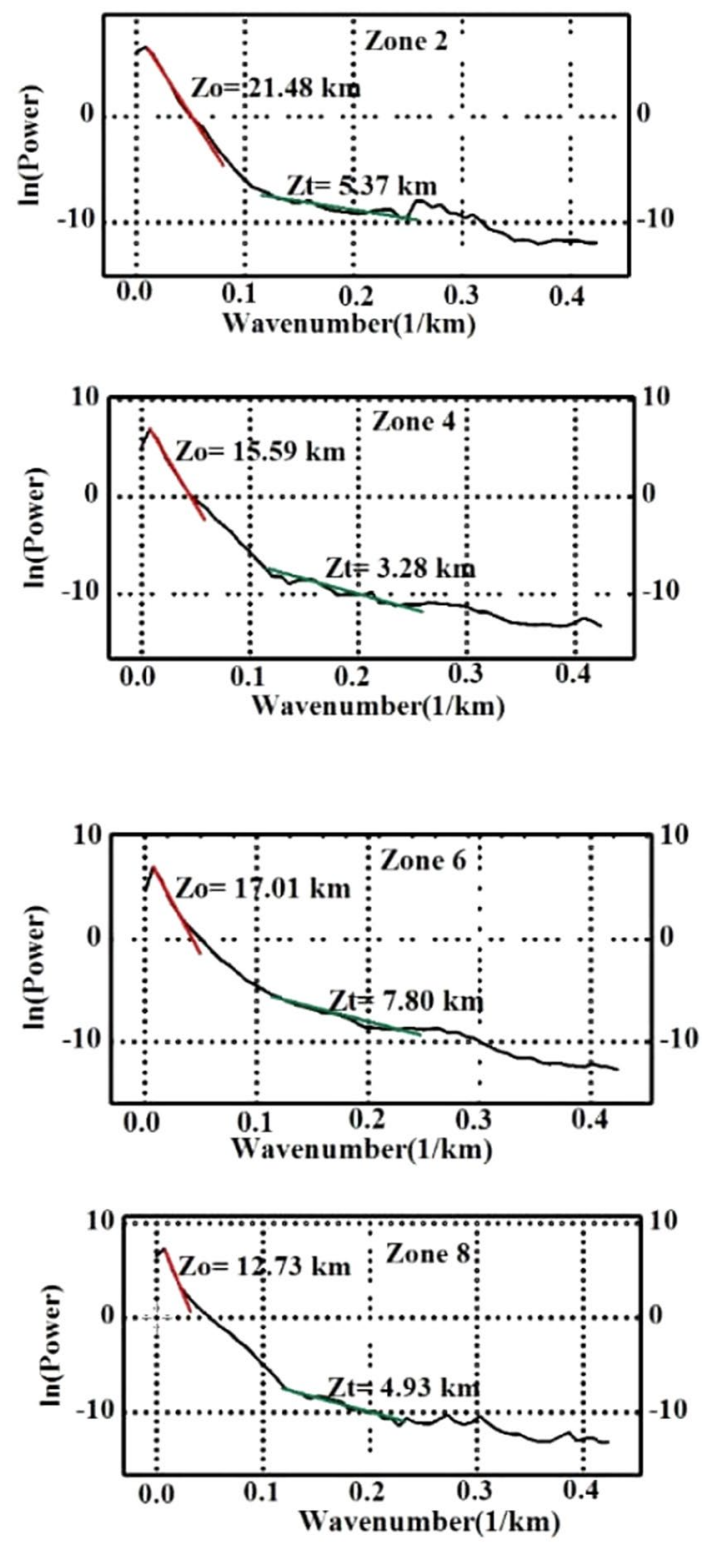

mating CPD of 4 zones. d Radially average power spectrum used for estimating CPD of 5 zones

to build individual facilities that exploit the energy recovered by fluids circulating in the ground at very shallow. Geological contexts such as sedimentary basins, subduction zones, and rifts have a geothermal gradient close to $30{ }^{\circ} \mathrm{C} \mathrm{km}^{-1}$. The temperature of the fluid collected varies abrupt manifestations in the release of internal energy. Finally, the increase of the temperature with the depth is a reality well known of the minors: The more a mine is deep, the more it is hot. Adamawa region (Cameroon) is located in an area with the crystalline basement. It will be possible 

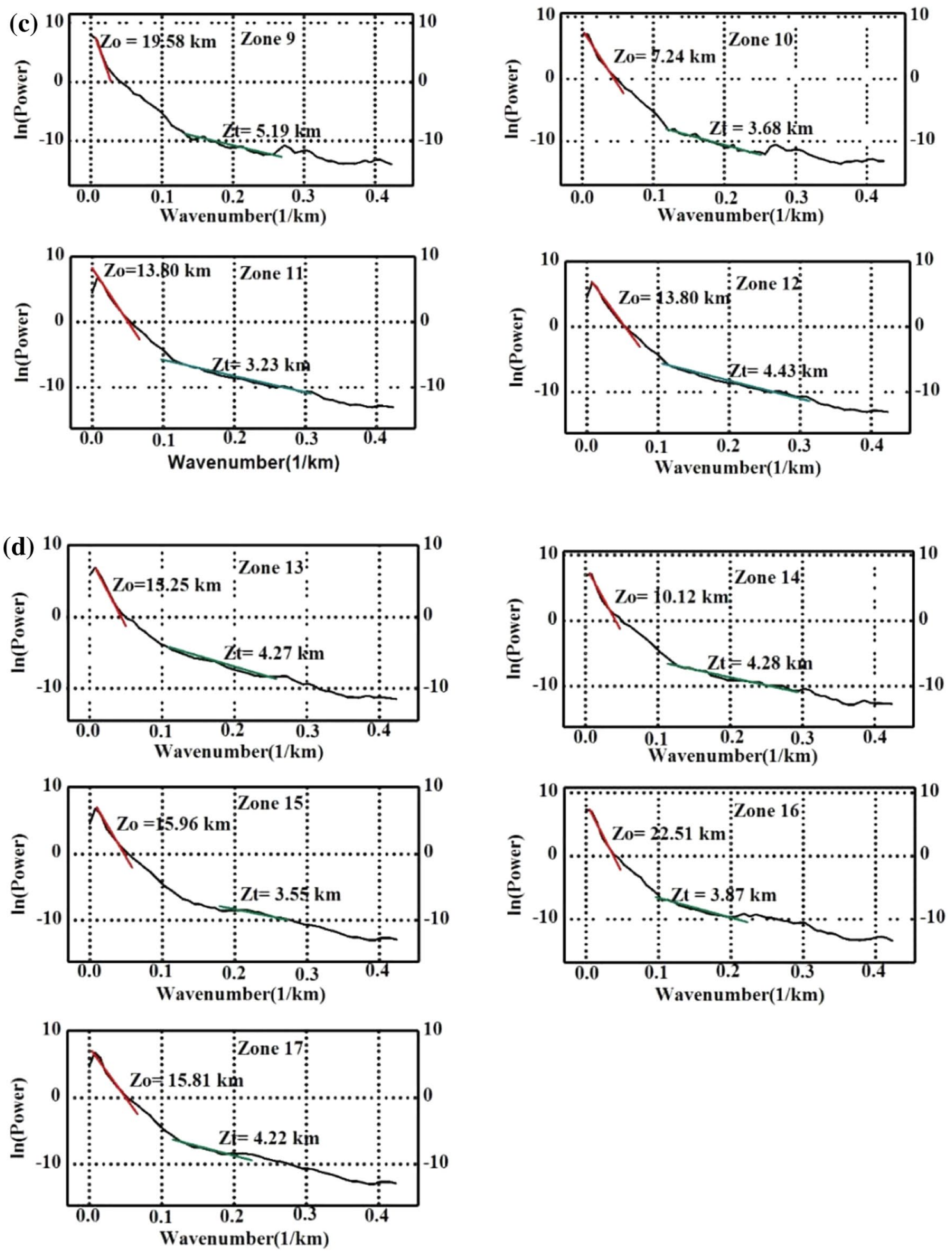

Fig. 5 (continued) 


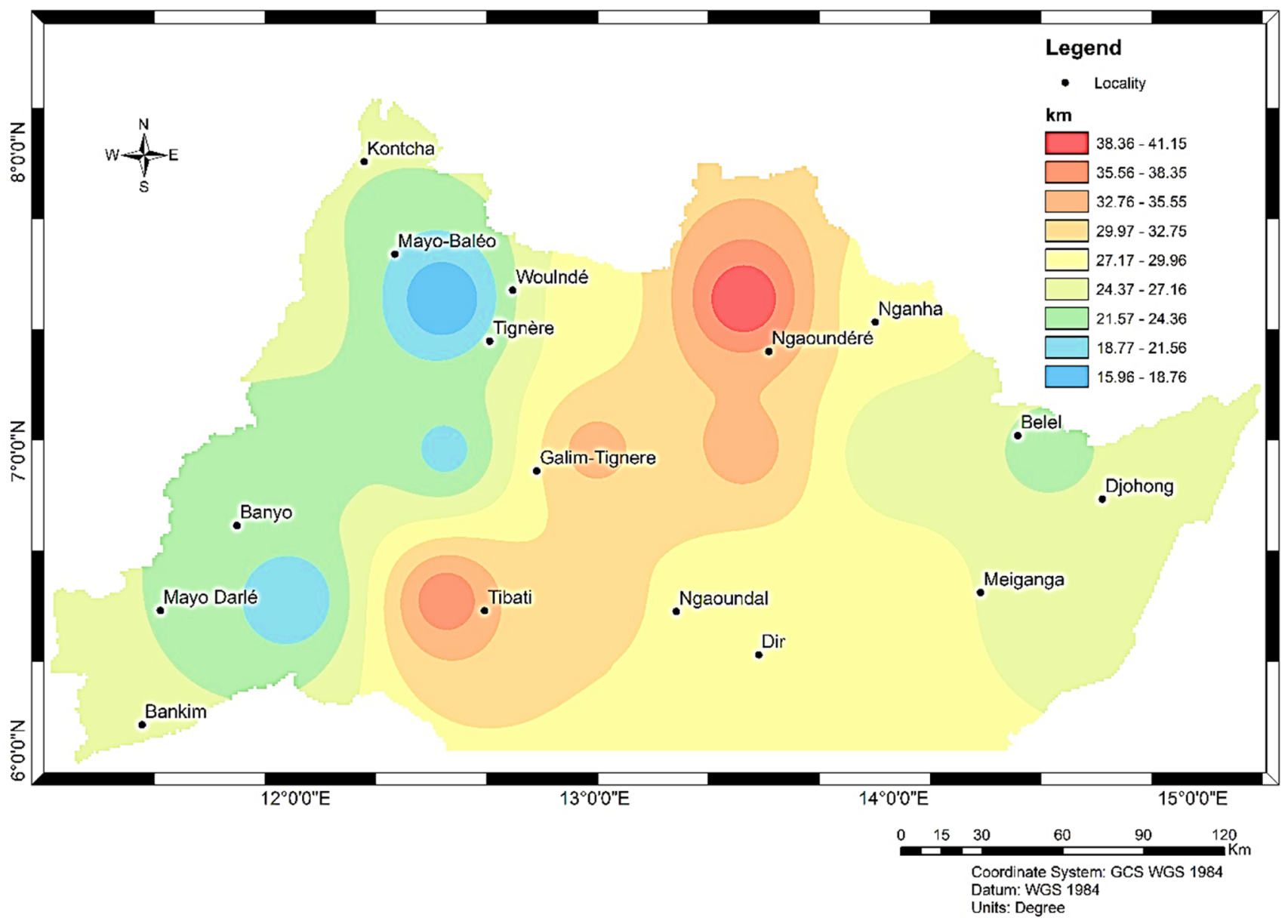

Fig. 6 CPD $\left(Z_{b}\right)$ map obtained from the spectral analysis of RTE data of Adamawa region. The counter interval is $15.96-41.15 \mathrm{~km}$

from 45 to $80^{\circ} \mathrm{C}$ as shown in Fig. 8. These results could justify a feasibility study for a small geothermal power station in the region. The resulting heat flow value is 55.681 $\mathrm{mW} \mathrm{m} \mathrm{m}^{-2}$ less than the average global heat flow value of $65 \mathrm{~mW} \mathrm{~m}^{-2}$ [49]. The obtained value corresponds to an equilibrium value between the deep part of the terrestrial mantle. Thermal convection and the continental crust where heat transfers are governed by thermal conduction. The localities of Woulndé, Mayo Baléo, and Tignère have a value of the heat flow having considerable geothermal 

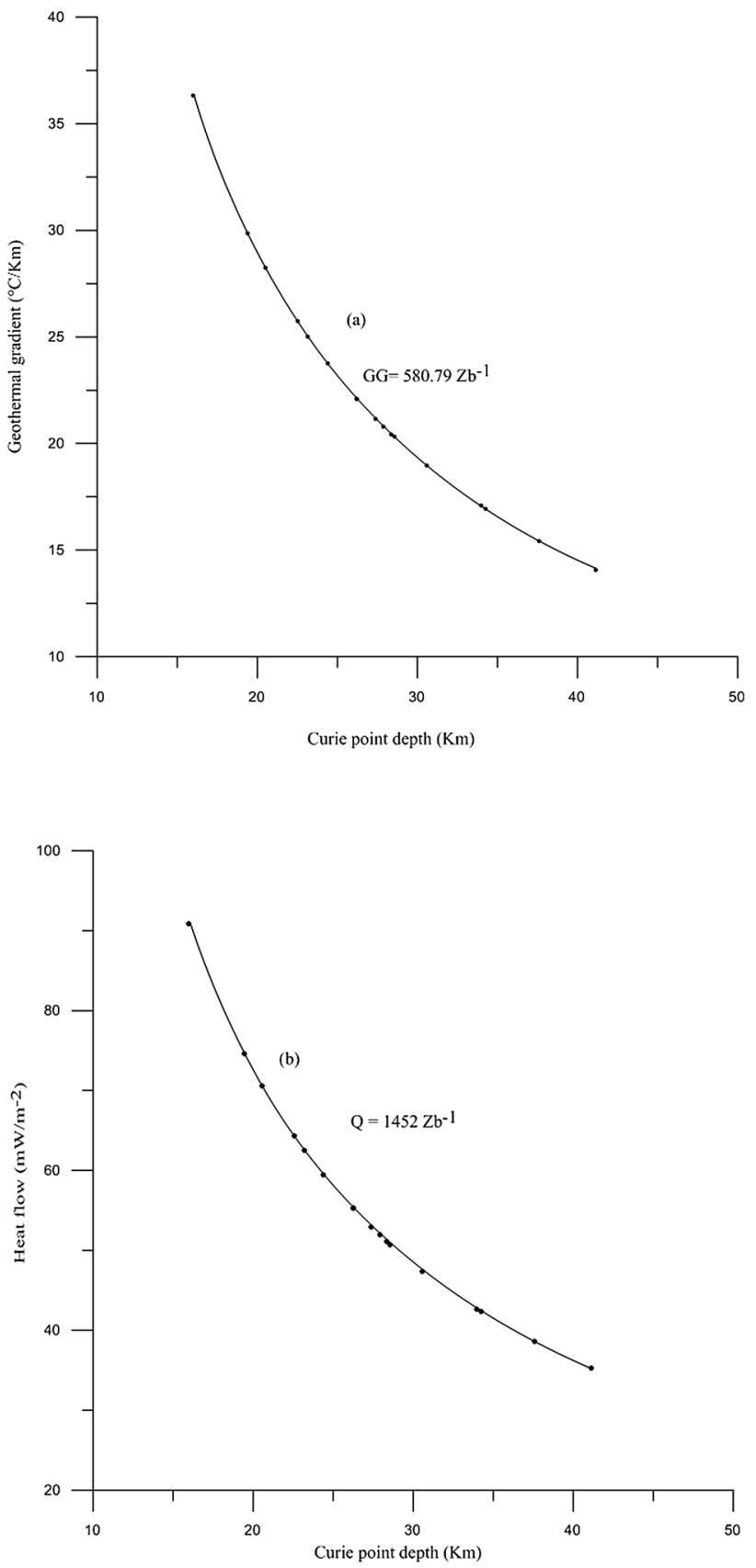

Fig. 7 The plot of Curie point depth versus of geothermal gradient (a) and heat flow values (b) in the Adamawa region energy of about $60 \mathrm{~mW} \mathrm{~m}^{-2}$ (see Fig. 9).This geothermal potential is located along the Cameroon Volcanic Line. The results obtained in this study correlate well with Ref.[25, 48].

\section{Conclusion}

This paper was devoted to the estimation of Curie point depth, heat flow and geothermal gradient deduced from spectral analysis over Adamawa volcanic region (northern Cameroon). Magnetic data were subjected to the equator-reduction procedure to eliminate magnetic sources. The mapped RTE data that was divided into 17 sub-zones. The inferred depth of the Curie points varies from $15.972 \pm 0.973$ to $41.158 \pm 1.078 \mathrm{~km}$ with an average of $27.526 \pm 1.020 \mathrm{~km}$. On the other hand, the heat flow in the study area varies between 35.22 and 90.85 $\mathrm{mW} \mathrm{m}{ }^{-2}$ with an average of $55.681 \mathrm{~mW} \mathrm{~m}^{-2}$. The geothermal gradient varies between 14.092 and $36.313^{\circ} \mathrm{C} \mathrm{km}^{-1}$ with an average of $22.273^{\circ} \mathrm{C} \mathrm{km}^{-1}$. This result shows that the Curie point depth inversely varies with the heat flow values. It was found that heat flow values with an equation of $Q=1452 \mathrm{Zb}^{-1}$ decrease with an increase in Curie point depth values. This result was proven that a shallow Curie point depth (less than $30 \mathrm{~km}$ ) and high heat flow values (greater than $80 \mathrm{~mW} \mathrm{~m}^{-2}$ ) exist in the Adamawa region. The results obtained in this paper reveals that the localities of Mayo Baléo, Tignère, Mayo Darlé and Woulndé have a hydrothermal geothermal potential to explore. These localities are recommended for a more detailed study to develop this source of clean energy for our environment. Also, the knowledge of the associated geological systems, as well as that of heat transfer in the underground open up development prospects for geothermal energy in this region. The geothermal potential of Cameroon, in this case, the source of Woulndé $\left(74^{\circ} \mathrm{C}\right)$ could be directly used for the following uses: Domestic hot water, aquaculture fish farming, the drying of agricultural products, wood, fish and recreation centers pool. 


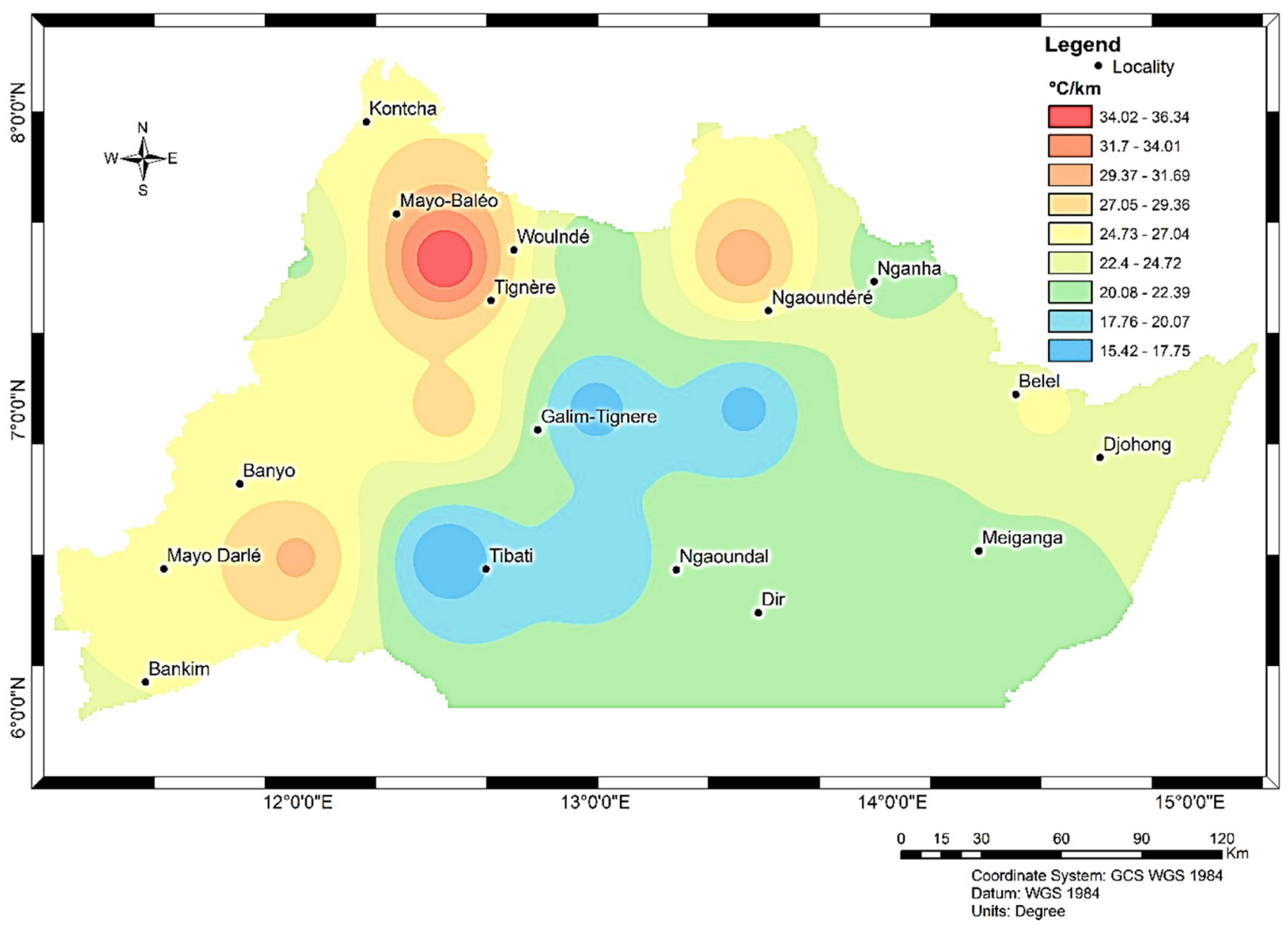

Fig. 8 Geothermal gradient map of Adamawa region derived from the CPD and Curie temperature of $580{ }^{\circ} \mathrm{C}$. The counter interval is $15.42-$ $36.34^{\circ} \mathrm{C} \mathrm{km}^{-1}$ 


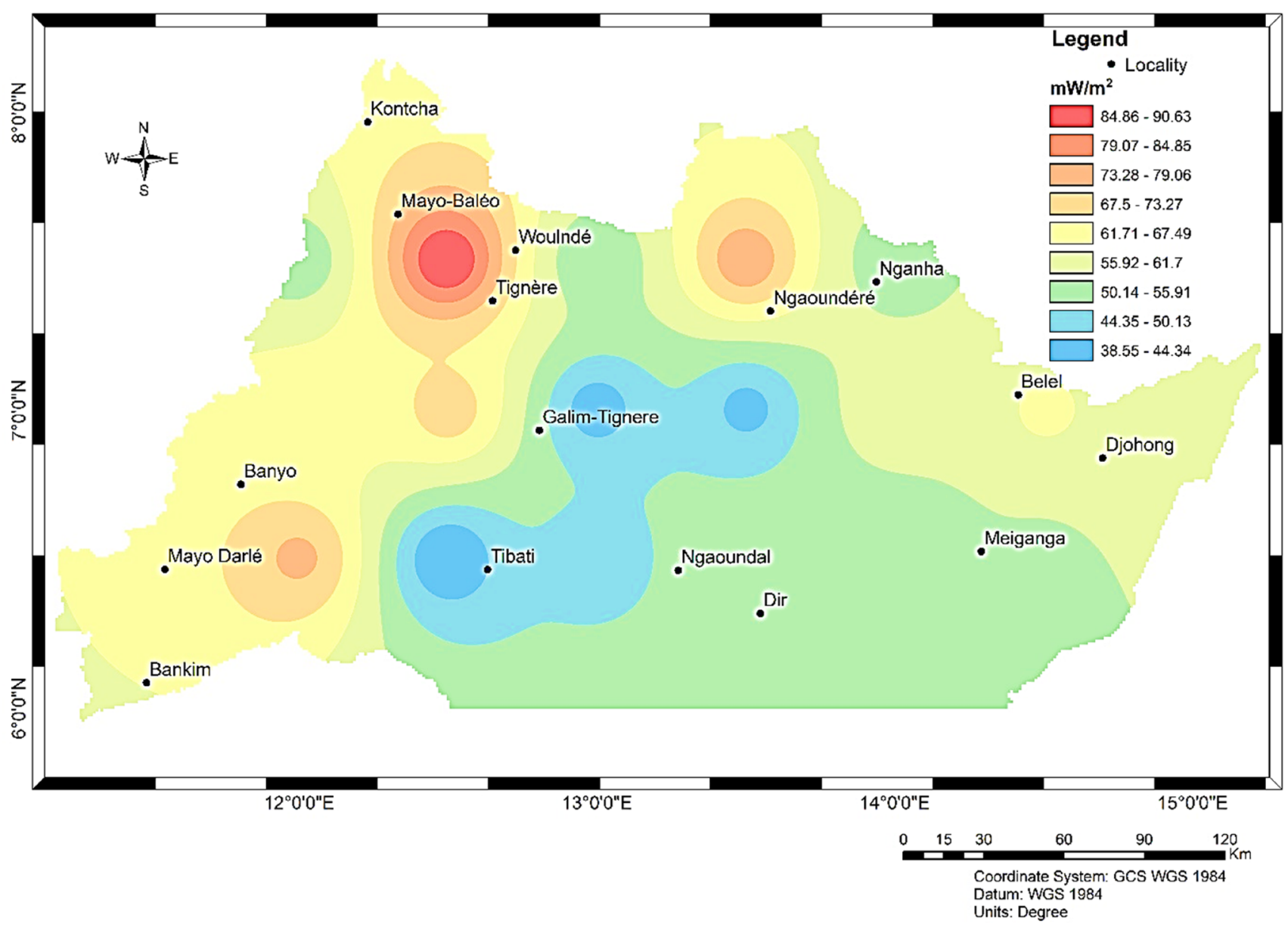

Fig. 9 Heat flow map of Adamawa region using an average geothermal conductivity of $K=2.5 \mathrm{Wm}^{-1} \mathrm{C}^{-1}$. The counter interval is $38.55-90.63$ $\mathrm{mW} \mathrm{m} \mathrm{m}^{-2}$

Acknowledgements Authors wish to thank Pr. Armand Fopah Lele, Dr. Edouard Mboumboue and Dr. William Assatse Teikeu for reading and providing valuable comments that helped to improve the manuscript.

\section{Compliance with ethical standards}

Conflict of interest The authors declare that they have no known competing financial interests or personal relationships that could have appeared to influence the work reported in this paper.

\section{References}

1. Gaudru H, Tchouankoue JP (2002) The 1999 Eruption of Mount Cameroon, West Africa. Co Geoenviron Newsl 18:12-14

2. Poudjom-Djomani YH, Nnange JM, Diament M, Ebinger CJ, Fairhead JD (1995) Effective elastic thickness and crustal thickness variations in West Central Africa inferred from gravity data. J Geophys Res 100(B11):22047-22070

3. Noutchogwe TC (2010) Investigation géophysique dans la région de l'Adamaoua par les méthodes gravimétriques et magnétiques : implications structurales et hydrogéologiques, Thèse de Doctorat/PhD Université de Yaoundé I

4. Nnange JM, Ngako V, Fairhead JD, Ebinger CJ (2000) Depths to density discontinuities beneath the Adamawa plateau region, Central Africa, from spectral analyses of new and existing gravity data. J Afr Earth Sci 30(4):887-901

5. Moreau C, Regnoult JM, Déruelle B, Robineau BA (1987) New tectonic modèle for the Cameroon Line, Central Africa. Tectonophysics 141(4):317-334

6. Dorbath L, Dorbath CW, Fairhead JD (1984) Structure de la croûte sous le plateau de l'Adamaoua (Cameroun). Comptes Rendus de l'Académie des Sciences 298(12):539-542

7. Dorbath L, Dorbath C, Fairhead JD, Stuart GW (1986) A teleseismic delay time study across the Central African Shear Zone in the Adamawa region of Cameroon, West Africa. Geophys. J. Int. 86(3):751-766

8. Tokam AP, Tabod CT, Nyblade AA, Julia J, Wiens AD, Pasyanos ME (2010) Structure of the crust beneath Cameroon, West Africa, from the joint inversion of Rayleigh Wave Group velocities and receiver functions. Geophys. J. Int. 183(2):1061-1076

9. Kande HL (2008) Étude géophysique de la structure de la croûte le long du fossé tectonique de la Mbéré (Sud Adamaoua - Cameroun). Université de Yaoundé I, Thèse de Doctorat/ PhD

\section{SN Applied Sciences}


10. Njeudjang K, Abate EJM, Domra KJ, Teikeu AW, Njandjock NP, Djongyang N, Tchinda R (2020) Gravity investigation of the Cameroon Volcanic Line in Adamawa region: geothermal features and structural control. J Afr Earth Sci. https://doi.org/10.1016/j. jafrearsci.2020.103809

11. Okubo Y, Graf JR, Hansen RO, Ogawa K, Tsu H (1985) Curie point depths of the Island of Kyushu and surrounding areas Japan. Geophysics 50(3):481-494

12. Blakely R.J., (1988). Curie temperature isotherm analysis and tectonic implications of aeromagnetic data from Nevada: Journal of Geophysical Research: Solid Earth; 93(B10): 11817-11832.

13. Onwuemesi AG (1997) One-dimensional spectral analysis of aeromagnetic anomalies and curie depth isotherm in the Anambra basin of Nigeria. J Geodyn 23(2):95-107

14. Tsokas GN, Hansen RO, Fytikas M (1998) Curie point depth of the island of Crete (Greece). Pure Appl Geophys 152:747-757

15. Tanaka A, Okubo Y, Matsubayashı O (1999) Curie-point depth based on spectrum analysis of the magnetic anomaly data in East and Southeast Asia. Tectonophysics 306:461-470

16. Dolmaz MN, Hisarli ZM, Ustaömer T, Orbay N (2005) Curie point depths based on spectrum analysis of aeromagnetic data, West Anatolian Extensional Province, Turkey. Pure Appl Geophys 162(3):571-590

17. Ross HE, Blakely RJ, Zoback MD (2006) Testing the use of aeromagnetic data for the determination of curie depth in California. Geophysics 71(5):L51-L59

18. Salah S, Salk M, Pamukcu O (2011) Estimating Curie point depth and heat flow map for Northern Red Sea Rift of Egypt and Its surroundings, from Aeromagnetic Data. Pure Appl Geophys 170(5):863-885

19. Nwankwo IL, Shehu TA (2015) Evaluation of Curie-point depths, geothermal gradients and near-surface heat flow from high-resolution aeromagnetic (HRAM) data of the entire Sokoto Basin. Nigeria. J Volcanol Geoth Res 305:45-55

20. Maden N, Afşin M, Aksever F, Davraz A (2020) Geothermal potential and circulation depth of Hüdai Thermal Springs (SandıklıAfyonkarahisar, Türkiye) using magnetic, geothermometry and heat flow data. In: Biswas A, Sharma S (eds) Advances in modeling and interpretation in near surface geophysics. Springer Geophysics. Springer, Cham

21. Odumodu CFR, Mode AW (2016) Geothermal Gradients and Heat Flow Variations in Parts of the Eastern Niger Delta, Nigeria. J Geol Soc India 88(1):107-118

22. Correa RT, Roberta M, Vidotti RM, Oksum E (2016) Curie surface of Borborema Province, Brazil. Tectonophysics 679:73-87

23. Elbarbarya S, Abdel Zaher M, Mesbaha H, El-Shahat A, Embaby A (2018) Curie point depth, heat flow and geothermal gradient maps of Egypt deduced from aeromagnetic data. Renew Sustain Energy Rev 91:620-629

24. Ahmad SH (2019) Imaging the Curie point isothermal surface and predicting its impact on the geothermal regime within the Nile Delta, Egypt. Egypt J Pet 28(1):77-90

25. Njinju EA, Kolawole F, Atekwana EA, Stamps DS, Atekwana EA, Abdelsalam MG, Mickus KL (2019) Terrestrial heat flow in the Malawi Rifted Zone, East Africa: Implications for tectono-thermal inheritance in continental rift basins. J Volcanol Geoth Res 387(10):66-56

26. Déruelle B, Ngounouno I, Demaiffe D (2007) The 'Cameroon Hot Line' (CHL): a unique example of active alkaline intraplate structure in both oceanic and continental lithospheres. CR Geosci 339(9):589-600

27. Guiraudie $C(1955)$ Carte géologique de reconnaissance à l'échelle du 1/500,000. Feuille Ngaoundéré-Ouest avec notice explicative (Dir. Mines et Géol. du Cameroun)
28. Lasserre M (1958) Etude géologique de la partie orientale de I'Adamaoua (Cameroun central) et les principales sources minéralisées de l'Adamaoua. Thèse faculté des sciences de Clermont Ferrand

29. Noutchogwe TC (2004) Investigations géophysiques en bordure du plateau de l'Adamaoua (Cameroun): rapport de la gravimétrie à l'étude de la croûte terrestre.Thèse 3ème cycle, Université Yaoundé I, Cameroun

30. Le Maréchal A (1976) Géologie et géochimie des sources thermo minérales du Cameroun: Thèse Univ, Paris VI. Cahiers ORSTOM 8(1):107-108

31. Maus S, Barckhausen U, Berkenbosch H, Bournas N, Brozena J, Childers V, Dostaler F, Fairhead JD, Finn C, Von Frese RRB, Gaina C, Golynsky S, Kucks R, Lühr H, Milligan P, Mogren S, Müller RD, Olesen O, Pilkington $M$, Saltus $R$, Schreckenberger $B$, Thébault E, Caratori Tontini F (2009) EMAG2: a 2-arc min resolution Earth Magnetic Anomaly Grid compiled from satellite, airborne, and marine magnetic measurements. Geochem Geophys Geosyst. https://doi.org/10.1029/2009GC002471

32. Oasis Montaj (2007) Geosoft Mapping and Application System, Inc, Suite 500, Richmond St. West Toronto, ON Canada N5SIV6

33. Arc-Gis E (2014) ArcGIS 10.2. United States of America

34. Shuey RT, Schellinger DK, Tripp AC, Alley LB (1977) Curie depth determination from aeromagnetic spectra. Geophys J R Astron Soc 50:75-101

35. Sandiford M, Hand M, Mac Laren S (1998) High geothermal gradient metamorphism during thermal subsidence. Earth Planet Sci Lett 163(1-4):149-165

36. Kasidi S, Nur A (2012) Curie depth isotherm deduced from spectral analysis of magnetic data over Sarti and Environs NorthEastern Nigeria. Sch J Biotech 1:49-56

37. Maden N (2012) Two-dimensional geothermal modeling along the Central Pontides magmatic arc (Northern Turkey). Surv Geophys 33:275-292

38. Maden N (2012) Geophysical approach for the detection and evaluation of geothermal energy potential stimulated from geology and tectonics in Cappadocia region (central Turkey). In: Yang J (ed) Geothermal energy, technology and geology. Nova, Hauppauge

39. Speranza F, Minelli L, Pignatelli A, Gilardi M (2016) Curie temperature depths in the Alps and the Po Plain (northern Italy): Comparison with heat flow and seismic tomography data. J Geodyn 98:19-30

40. Nguiya S (2009) Investigation géophysique du bassin volcanosédimentaire de Lom (Est-Cameroun) : implications structurales et tectonique, Thèse de Doctorat/PhD Université de Yaoundé I

41. Majorowicz JA, Jessop AM (1981) Regional heat flow patterns in the western Canadian sedimentary basin. Tectonophysics 74(3-4):209-238

42. Majorowicz JA (1996) Anomalous heat flow regime in the western margin of the North American craton, Canada. J Geodyn 21(2):123-140

43. Omoko FA (2013) Projet de conception et réalisation d'une centrale électrique géothermique de $5 \mathrm{Mw}$ au Cameroun. Mémoire pour l'obtention du master 2 spécialisé en génie électrique énergétique et énergies renouvelables option: énergies renouvelables 2ie Burkina Faso

44. Domra KJ, Djongyang N, Danwé R, Ramandhan BT (2017) Appraisal of geothermal resources and use in Cameroon. Afr J Sci Technol Innov Dev 9(6):661-667

45. Regan RD, Cain JC, Davis WM (1975) A global magmatic anomaly map. J Geophys Res 80(5):784-802

46. Regan RD, Marsh BD (1982) The Bangui Magnetic anomaly: its geological origin. J Geophys Res: Solid Earth 87(B2):1107-1120 
47. Nnange JM (1991) The crustal structure of the Cameroon volcanic line and the Foumban Shear Zone based on gravity and aeromagnetic data. PhD/thesis. University of Leeds, England

48. Kasidi S, Kamureyina E, Joshua PT (2018) Estimation of Curie depths, heat flow and geothermal gradient of Mubi and Environs North Eastern Nigeria. J Geogr Environ Earth Sci Int 18(4):1-8
49. Pollack HN, Hurter SJ, Johnson JR (1993) Heat flow from the Earth's interior: analysis of the global data set. Rev Geophys 31(3):267-280. https://doi.org/10.1029/93RG01249

Publisher's Note Springer Nature remains neutral with regard to jurisdictional claims in published maps and institutional affiliations. 